\title{
Optimizing of the Independence role on Performance Increase through the Comfortness of Auditors of Local Governments
}

\author{
Lismawati $^{1 *}$, Abdul Rohman $^{2}$, Anis $^{\text {Chariri }}{ }^{2}$ \\ ${ }^{1}$ Department of Accounting, Universitas Bengkulu, Indonesia \\ ${ }^{2}$ Department of Accounting, Universitas Diponegoro, Jl. Prof.H.Soedarto, S.H.Tembalang, Tembalang, \\ Kota Semarang, Jawa Tengah 50275, Indonesia
}

\begin{abstract}
Inadequate implementation of the role of assurance and consulting internal auditor performance in making local governments has not been optimal.The study aims to verify the comfortness of auditors is able to mediate the relationship of the increase of the independence and the performance of the internal auditorsof local governments in Indonesia. The empirical evidencesare collected by the online and offline survey (through the postal services) to the internal auditors of local governments. By employing the one of structural equation model, namely the partial lease squares, the study finds that the comfortness of the auditors is able to mediate the relationship between the independence and the performance of the auditors. The findings of the study is expected to provide the idea of the development of local government auditors studies in Indonesia.
\end{abstract}

Keywords: Independence, Comfortness, Performance

\section{Introduction}

The auditor's performance is a result of the achievement of a work or one's work achievements auditor. Performance is the result of work the auditor in carrying out the duties charged to him based on skills, experience and knowledge that are owned [1]. Performance can also be interpreted as the work of either the quantity or quality of a task terkai auditing auditor stepped her responsibilities [2].

The auditor should be able to achieve the best performance in carrying out the audit assignment, the internal auditor was no exception. The internal auditor of the government is the party that is running against the course of supervision function of wheels of government. The internal auditor of the government particularly the APIP in this case is the Inspectorate must be able to demonstrate the best performance even though it was under command of the head of the region. The success of auditor in carrying out the oversight function in local government will be able to reduce a variety of fraud [3].

Fraud happens in local government raises various questions related to the internal auditor's role in optimization. A lot of fraud going on in local government indicated yet the proper functioning of the internal auditors performed the role. As contained in difinisi of the audit, there were two important roles is assurance role konsulting[4]. But the two roles have not been going well.

A range of fraud had occurred almost throughout the local government in Indonesia. Many of the head area that caught the bribery and corruption to the detriment of the area's financial impact on obstructed various government development in the local area. Most of the fraud that occurred in local government is a fraud involving the head of the region. The case caught the hand of the Governor of Bengkulu related fee development projects of existing road infrastructure in the province of Bengkulu to make public question performance of internal auditor of government. Moreover the results of audit report of the financial accountability of local government of Bengkulu province have reasonable opinion without exceptions. This contradictory phenomenon makes the public wonder whether existing internal auditor in local government has run well role. Whether in the exercise of internal audit, auditor has to uphold an independent attitude in examining various irregularities. If the auditor feels fear or hesitate when should uncover the facts relating to the head area that in fact is the boss. This research tries to reveal what is true there is the relevance of the relationship between the enforcement of Independent auditors on performance attitude. What is auditor greatly comfort affect the success of auditors in achieving the best performance.

\footnotetext{
*Corresponding author: lismawati390@gmail.com
} 
Previous research has succeeded in proving the existence of a direct relationship between the independence toward improved performance. The research of Bhagat and Black (2001); Dewi et al., 2015; Lin et al., 2017[5], has successfully tested direct relationship between independence on performance. However, a direct relationship between the independence of auditors on performance terlemahkan by research Ma'ayan and Carmeli (2015). Ma'ayan and Carmeli (2015) succeeded in proving the existence of an indirect relationship between the independence of auditors on performance through learning audit.

Research Ma'ayan and Carmeli (2015) only consider variable learning audits that are able to mediate relations of independence of auditors on performance. A lot of other variables that have not been considered in research and Ma'ayan Carmeli (2015). Given the problems faced by the auditor in carrying out internal audit needs to be extremely complex, may consider other variables that can mediate relationship against independence of auditor's performance.

This research seeks to provide psychological comfort in the form of an auditor who will mediate the relationship of performance against the independence of the auditor. Consider comfort important audit examined given internal auditor as practitioners will think of convenience when assessing the quality of their work was affected with the emotion of his actions $^{6}$. Therefore, this research try connecting factor on performance auditor independence through psychological aspects form the comfort of an auditor that has never been considered in previous studies.

\section{Methodology}

This research uses theoretical basis of attribution theory Heider Frizt introduced the year 1958 in linking relationships the independence of auditors on performance and auditor comfort. Meanwhile a relationship of convenience against auditor auditor's performance is based on the comfort theory developed Kolcaba year 1991. Attribution theory describes the process of how to determine the causes and motives of the person's behavior, whether his behavior is determined from the internal attribute is inside or external attributes that reside outside of one's self. Internal and external attributes attribute has been declared may affect the decision of the individual to work or work achievement as well as the resulting actions[7]. While the comfort theory identifies three technical meanings concept of comfort is State, renewal (renewal) and rest/relief (relief) which covers aspects of the physical, environmental, and social aspects of psikospiritual[8]. The example of comfort theory is when auditors can enjoy the natural environment that can support work so that it supports social and psychospiritual aspects to get maximum work results.
This research is a survey research using primary data. Primary data were obtained from the respondent's answers to some of questions asked through instruments of research that has been developed Robbins (1996); Tepalagul and Lin, (2015) as well as the Ekstrom and Persson (2015). The choice of answers to the research instrument using five scale likers. The respondents of the research is the internal auditor of local government in Indonesia totalling 138 people. The dwarf in the selection of sample based in cluster sampling. This research uses SEM_PLS in doing data analysis with the program WarpPLS 5 .

\section{Discussion}

Here are presented the results of the research hypothesis testing is shown in figure 1.

Empirical Model Research

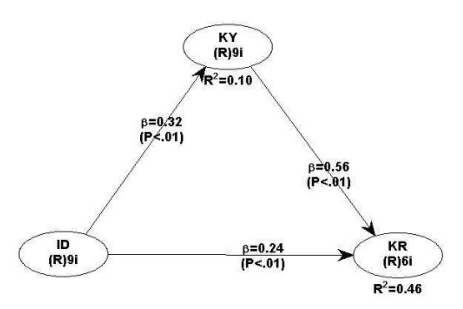

Figure 1

Table. 1 Conclution Hypothesis Testing

\begin{tabular}{|l|c|c|c|}
\hline & Table. 1 Conclution Hypothesis Testing \\
\hline Hypotesis & P-Value & Koefisien & Decision \\
\hline ID - KR & $0,01^{*}$ & 0,24 & Accepted \\
\hline ID - KY & $0,01^{*}$ & 0,32 & Accepted \\
\hline
\end{tabular}




\begin{tabular}{|l|l|l|l|}
\hline $\mathrm{KY}-\mathrm{KR}$ & $0,01^{*}$ & 0,56 & Accepted \\
& & & \\
\hline
\end{tabular}

Assumptions: ${ }^{*} \mathrm{p}<0.01$ (one-tailed)

Based on table 1 visible hypothesis one related relationship of independence towards the performance of auditors produce numbers of 0.24 and coefficient significant at 0.01 which means that one hypothesis is accepted. He received one hypothesis means getting an independent auditor will be able to produce increasingly better performance.

Independence is a mental attitude that is free of influence, not controlled and does not depend on any other $^{8}$. The independence of auditor regarding self honesty in considering facts and objective in formulating and asserting opinions. The success of the auditor in enforcing independence of attitude will generate a quality audit. A quality audit showed the success of the performance auditor. A quality audit will boost public confidence over audit done.

\section{Conclusion}

The results of this research have supported the existence of attribution theory developed Frizt Heider. The attitude of the independence auditor who is atrubut internal auditor has been shown to have an impact on improving the performance internal auditor of government. The results of this research also suggests importance of the government's internal auditor will in fact revealed for what it is though facts involving the head area as superiors. The results of this study are consistent with the results of research conducted[9].

The test results against two related hypotheses of relationships against the independence of auditors produce convenience coefficient of 0.32 and significant at $p>0.01$ which means that the two hypotheses are accepted. The more independent auditors will be more comfortable in doing the work of the audit. If internal auditors the government intervened, it will make the auditor are not comfortable in carrying out audit assignments. Independence of auditors can provide a sense of relief, free and brave in doing audit against anyone included the head of the region that was also President of the internal auditor of the government. The results of the three hypotheses have been successfully supporting attribution theory. The independence which is the attribute of the internal auditor will be able to bring a feeling of auditor comfort.

The results of hypothesis testing three related relationship auditor's performance against the convenience yield coefficient of 0.56 and significant at $\mathrm{p}>0.01$ which means that third hypothesis is accepted. The higher the auditor comfort then will the better the resulting performance of auditor. The results of these studies support the concept of the comfort theory developed Kolcaba year 1991. The perceived convenience of auditors will motivate auditor in the internal audit that was able to produce the best performance.

\section{References}

1. L. Piciullo, S. L. Gariano, M. Melillo, M. T. Brunetti, S. Peruccacci, F. Guzzetti, and M. Calvello. Definition and performance of a threshold-based regional early warning model for rainfall-induced landslides. Landslides: p. 1-14 (2016).

2. A. B. C. Douss, R. Abassi, and S. G. El Fatmi, $A$ trust-based security environment in MANET: definition and performance evaluation. Annals of Telecommunications 72 (7-8): p. $491-498$ (2017).

3. S. Naidoo, The South African Criminal Law's response to the crimes of fraud and corruption within local government, Dissertations University of Pretoria (2017).

4. C. S. Yee, A. Sujan, K. James, and J. K. Leung, Perceptions of Singaporean internal audit customers regarding the role and effectiveness of internal audit, Asian Journal of Business and Accounting 1 (2): p. 147-174 (2017).

5. P. Broberg, The auditor at work: A study of auditor practice in Big 4 audit firms. Dissertation Department of Business Administration, School of Economics and Management, Lund University (2013).

6. FX. Luthans, Organizational Behavior, McGrawHill, New York (2015).

7. A. C. Mustamu, Aplikasi Teori Kenyamanan Katharine Kolcaba Jurnal Keperawatan alvamustamu, 23 (2): p. 234-239 (2014).

8. I. S. Pinto, and W. N. Picoto, Professional ethics and governance: understanding appraiser independence, International Journal of Business Governance and Ethics 11 (4): p.290-312 (2016).

9. Y. -C. Lin, Y.-H. Lu, F.-C. Lin, and Y.-C. Lu, "Net Losses and The Relationship Between Auditor Independence and Client Importance: Evidence From a Cubist Regression-Tree Model", Journal of Emerging Technologies in Accounting, 4 (2): p. 21-32 (2017). 